$\mathrm{K} \rightarrow 40 \mathrm{~K} \rightarrow 90 \mathrm{~K}$ と液体窒素温度まで突破してしまった のである.正にダークホースである.零抵抗，マイスナー

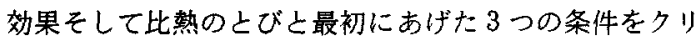
ヤーして，正真正銘の超伝導物質であることが確寒上 なっている， $T_{\mathrm{c}}=90 \mathrm{~K}$ というのは, どう頑張っても BCS 機構では説明が難しいであろう。これらの酸化物 は，いずれも層状の構造をもつ。したがって理論的に予 言されたエキシトン機構にとって理想的な状況になって いるのかもしれない，一方，銅は $3 \mathrm{~d}$ 電子系で，酸化物 中での電子の局在性もかなり強いと考えられる。した がって，これらの物質中の電子間には，かなり強いクー ロン斤力が㗢いていそうである。つまり重いフェルミ粒 子系上似たような状況であるともいえる. 今のところ高 温超伝導の実現にどちらが決定であるのかはっきりしな い.
ここに紹介した、いくつかの物質群の中から，酸化物 が頭角を現わし，一早く液体窒素超伝導を実現してし まった．それ以外の物質は、いまだに $23 \mathrm{~K}$ の壁を破れ ずにいる，次の目標は，室温超伝導となったが，酸化物 系が他を椡的に引き離してしまったために，現実に考 え得る唯一の物質系という状況になっている，それを旁 付けるように, 最近 $\mathrm{Y}-\mathrm{Ba}-\mathrm{Cu}-\mathrm{O}$ を主体とした, や はり銅の酸化物で，“その”兆候が世界のあちこちで観 測され始めた. 今のところ, 超伝導状態, あるいはそれ を引き起こしている物質自体が不安定で，再現性にも欠 けるが、このまま一気に室温超伝導が実現してしまう可 能性もある. 夢であった窒素温度超伝導だけでなく，夢 のまた夢である室温超伝導までも，酸化物は実現してし まうのであろうか？

\title{
2 酸化物伝導体の特徵之高温超伝導
}

\author{
佐 藤 正 俊
}

\section{1 はじめに}

現在話題となっている高温超伝導体はその基本構造 (図 1) から $\left(\mathrm{La}_{1-x} \mathrm{M}_{x}\right)_{2} \mathrm{CuO}_{4-\delta}(\mathrm{M}=\mathrm{Ba}, \mathrm{Sr}$ および $\mathrm{Ca})$ と $\mathrm{LnBa}_{2} \mathrm{Cu}_{3} \mathrm{O}_{7-\delta}(\mathrm{Ln}=\mathrm{Y}$ およびランタニド元 素）の 2 つにわけられる，それらは超伝導転移温度上昇 に関する研究の長い停滞ののち突如現われたという意味 で大変センセーショナルである.しかし高い転移温度 (high-T $\left.T_{\mathrm{c}}\right)$ が説明される明りょうな特徵を有している かというとなかなかそうでもない，筆者らは今回の騒ぎ の火付け役である Bednorzや Müller ${ }^{1)}$ と同様長年酸 化物超伝導探索に携わってきた2”ので，高温超伝導体と 他の酸化物との差異についてよく質問をうけたが，明快 な返答はできなかった。これに答えるためにはおそらく （1）他の類似超伝導酸化物系を発見して共通の性質をし らべる，(2) 上記既知の系を丹念にしらべること，等が 必要亡思われる. 筍くべき多数の人々が研究に寄り集 まってきたとはいえ，なにしろまだ本格的研究が始まっ て半年である. しかも論文には重複する内容のものが数 多くそれらの交通整理も完全ではない，メカニズムや物 質の個性が現象に反映されにくいのか特徵である超伝導 の理解のためによ゙の物理量に注目すれば良いかも現時点 では断じがたい，筆者らも(1)，(2)の双方の観点から 分子科学研究所 (广 444 岡崎市明大寺町西揤中 38 )
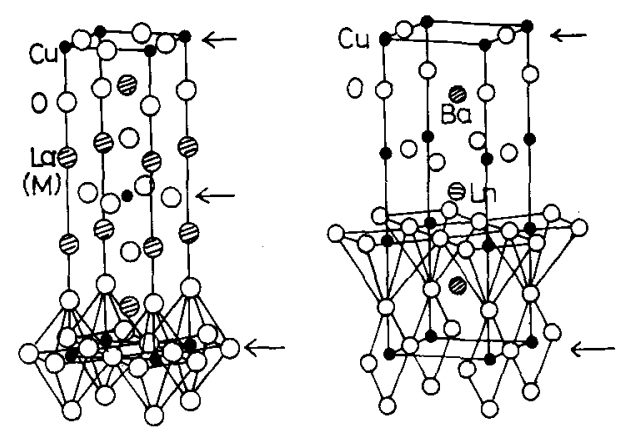

図 $1\left(\mathrm{La}_{1-x} \mathrm{M}_{x}\right)_{2} \mathrm{CuO}_{4}$ (左) と $\mathrm{LnBa}_{2} \mathrm{Cu}_{3} \mathrm{O}_{7}$ の模式図 酸素の八面体等のユニットが見やすいように一部ユニットセル 外の酸素も含めて示し線でつないだ. 知の面で 0 原子が抜け やすい

あわただしく研究を進めてきたのみであり，皆の研究成 果を公平に見渡す余裕などないので，ここでは気づくま まに偏った稿を書いてみることにする。

\section{2 酸化物導体の特徵と高温超伝導体}

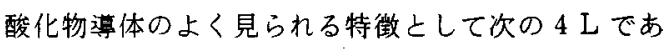
らわされる互いに関連した事がらが挙げられる.

(i) Linkage of Oxygen Units such as $\mathrm{TO}_{6} \mathrm{Oc}$ - 
tahedra ( $\mathrm{T}$ ：息移金属元素)

(ii) Low Dimensional Conduction

(iii) Low Carrier Density

(iv) Large Electron Affinity of Oxygens

少なくとも従来の超伝導は電子格子相互作用による

（格子振動ニフォノンを媒介として生ずる引力に上る）

電子対 (クーパーペア) 形成でひきおこされる現象であ るが，筆者らは上記 4 つの特徵之強い電子格子相互作用 の可能性とを結びつけて考元，酸化物伝導体における高 温超伝導探索を行ってきた(これらのことについては文 献 2 に記述があるので省略する)．またこれらの酸化物 のうちのいくつかを金属層（鎖）亡絶緑体層（鎖）がミ クロな意味で隣接した系としてとらえ, 絶縁体部に存在 するであろう電子励起（エキシトン）を媒介にしたクー パーペア形成をも夢見てきた ${ }^{2.3)}$. 電子格子相互作用が 強くなると格子が不安定になり構造相転移がおこるため T圤上があるようなのに対し，エキシトン介在をメ カニズムとする超伝導では，エキシトンのエネルギース ケールが大きいことから $T_{\mathrm{c}}$ の上限がないに等しい、い ま $T_{\mathrm{c}} \geq 90 \mathrm{~K}$ の $\mathrm{LnBa}_{2} \mathrm{Cu}_{3} \mathrm{O}_{7-\delta}$ が発見されるに至っ で，このような電子励起介在等の新しいメカニズムを 多くの人々が考えるようになったこよは今後の研究の成 り行きを待たねばいけないにせよ，夢が現実になる可能 性を秘めており大変なことである.

もちろん（i ）（iv）の上うな特徴をもったものすべ てが高温超伝導を示すわけではない，われわれが以前 扱ってきたモりブデンブロンズ $\mathrm{M}_{x} \mathrm{MoO}_{3}$ や類似酸化物 でも超伝導を示さず電荷密度波を伴った構造相転移をお こして絶縁体または半金属相へと移行するものが多かっ た.この類いの椪造相転移は特に低次元導体でおこりや すいことが簡単な議論から知られているので, フォノン を介在とした従来の超伝導においては, 電気伝導の低次 元性はむしろ歓迎されないものである. その意味で $\mathrm{Pb}$ ( $\mathrm{Bi}) \mathrm{O}_{6}$ 八面体が頂点を共有して三次元的に積み重なっ たペロブスカイト型化合物 $\mathrm{BaPb}_{1-x} \mathrm{Bi}_{x} \mathrm{O}_{3}$ が他に比較 して高い転移点( $11 \mathrm{~K}$ )をもつのだと考えられたこと もあった。

さて今回発見された高温超伝埕体についてその特徽を 詳しく見てみよう，他の酸化物同様、酸素のユニットの 連結で構成されているのは図 1 に示されているとおりで ある、ただしあるサイトの酸素がかなり自由に抜けてし かもそれによって構造の大きな变化がない. 図 1 の知印 の面内の酸素が抜けやすい，しかしこの酸素がなるべく 抜けずに化合物内に踏みとどまったとき $T_{\mathrm{c}}$ が高くな る. $\mathrm{O}^{2-}$ の数が多いほど $\mathrm{Cu}^{3+} も し く は[\mathrm{Cu}-\mathrm{O}]^{+}$の数 が多いわけであるが実は $T_{\mathrm{c}}$ はこの正イオンの数，すな わちバンド内の電子空孔 (hole) の数でスケールされ. それが多いほど $T_{\mathrm{c}}$ が高くなる5゙。これに対しモリブデ

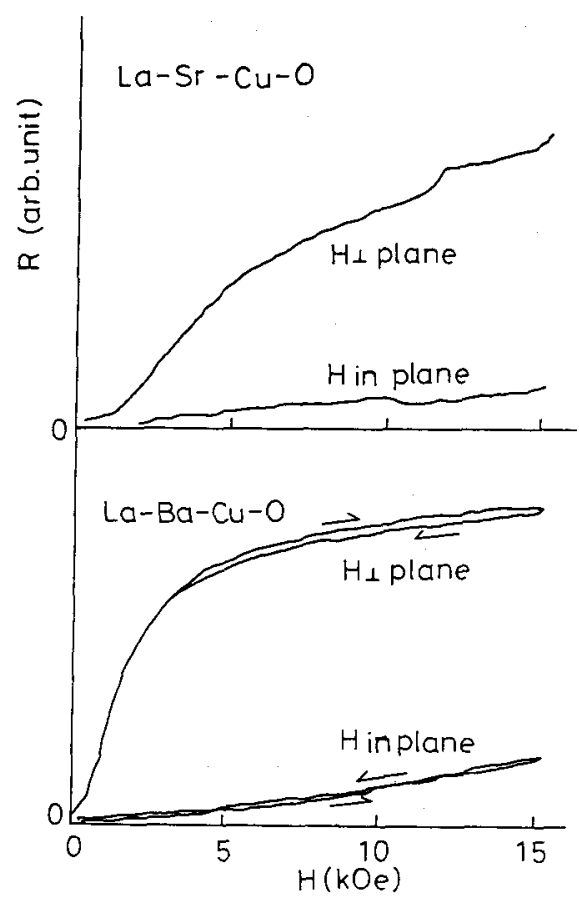

図 2 抵抗の磁場依存性

上が $\left(\mathrm{La}_{1-x} \mathrm{Sr}_{x}\right)_{2} \mathrm{Cu}-\mathrm{O}_{4-s}\left(T_{\mathrm{C}} \sim 13.5\right)$ 下が $\left(\mathrm{Lat}_{1-x} \mathrm{Ba}_{x}\right)_{2}$ $\mathrm{CuO}_{4-\delta}\left(T_{\mathrm{C}} \sim 8.5 \mathrm{~K}\right)$ 単結晶試料を用いた $x \leq 0.075$. 磁堨の方向 による $H_{\mathrm{c} 2}$ の異方的振舞力顕著である

ンブロンズ, $\mathrm{M}_{x} \mathrm{MoO}_{3}$ 等ではアルカリ原子 $\mathrm{M}$ からバン ド内に放出された電子が伝導を担っており電荷のバラン スから見て酸素が拔けやすい形にはなっていない.

図 2 に $\left(\mathrm{La}_{1-x} \mathrm{M}_{x}\right)_{2} \mathrm{CuO}_{4-\delta}(\mathrm{M}=\mathrm{Sr}$ 扰上び $\mathrm{Ba}, x \leq$ $0.075)$ の单結晶について上部臨界磁場 $H_{\mathrm{c} 2}$ を測定した 例を示す ${ }^{6)}$ ，筆者らは世界で初めて，今回注目されてい る系の単結晶試料を作成したが図には Ba を含む $T_{\mathrm{c}}=$ $8.5 \mathrm{~K}$ のものと $\mathrm{Sr}$ を含む $T_{\mathrm{c}}=13.5 \mathrm{~K}$ の単結晶について の結果を示したにこで $T_{\mathrm{c}}$ は抵抗の常伝導時の半分に なる温度をとる). $T_{\mathrm{c}}$ が一般に知られている値より低い のは，おそらく結晶作成時に酸素の欠損がはいるためて あろう。磁場方向の違いによる $H_{c 2}$ の大きさの違いが 一目りょう然である.電気伝導率の面内 $(11)$ ・面間 $(\perp)$ 異方性 $\sigma_{11} / \sigma_{-} は\left\{H_{\mathrm{c} 2 \| 1} / H_{\mathrm{c} 2-}\right\}^{?}$ と近似するのが良い (ここでリとよはそれぞれ磁場が面内お上び面に垂直の 場合を表わす)ことが知られているので，これを使って みると $\mathrm{Sr}$ の化合物では $\sigma_{\|} / \sigma_{-} \sim 40, \mathrm{Ba}$ の化合物では $\sigma_{||} / \sigma_{-} \sim 170$ 上いう結果が得られ顕著な 2 次元的伝導性

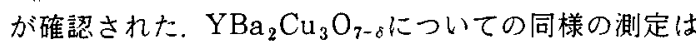
その後日高氏達および家氏達 ${ }^{7}$ によって行われたが, や はり伝導度に大きな異方性があると考えられる。

伝導電子数は，たとえば $\left(\mathrm{La}_{1-x} \mathrm{Sr}_{x}\right)_{2} \mathrm{CuO}_{4-\delta}(x \sim$ $0.075)$ で $2 \times 10^{21} / \mathrm{cm}^{3}$ 程度 ${ }^{8}$ であり通常の金属に比較 
して小さい，このような低キャリア濃度と低次元伝導性 とは必ずしも互いに独立なことではないかもしれない が, ともかくそういう状況下では電子が一部に偏在する ことや，電子間および電子と格子のクーロン相互作用の しゃへい効果が弱くなることなどから，超伝導に都合の 良い相互作用が有効になるケースが出てこないだろう か、Varma ら"が議論したエキシトン介在の超伝導も この状況を念頭においてのことである，彼らは $\mathrm{Cu}$ 原子

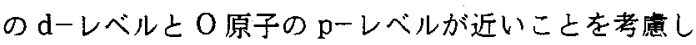
ているが，これは他の酸化物とは大きく違った特徽であ る.なお Kresin ら ${ }^{10)}$ は低次元電子系でプラズモンと 呼ばれる電子励起が有効になると主張している.

$\mathrm{LnBa}_{2} \mathrm{Cu}_{3} \mathrm{O}_{7-\delta}$ の $T_{\mathrm{c}}$ は $\mathrm{Ln}$ 原子の持つ磁気モ一メ ントの大きさには影響されない，これは筆者らが最初に 指摘した ${ }^{11}$ ことである。一般的に言えば超伝導体内の

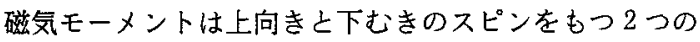
電子から成るクーパーペアをそのスピン散乱によって破 壊する作用をもつ，上記超伝導体がそうならないのは， Ln原子サイトの層に伝導電子が存在せず，したがって スピン散乱もないからだと考えられる。

伝導電子数が少ないと電子局在の問題が生じるのは超 伝莩にとって歓迎できない面である，詳しい議論は省略 するが物質内のミクロな乱雑さ，たとえば空孔や原子お きかえによる不規則性が電子局在をひきおこす，これは 伝導電子のエネルギーが小さいほど，すなわち伝導電子 数が少ないほど顕著にあらわれる. その意味で酸素欠損 等をできるだけ導入しない努力が必要となるが今の場合 は，むしろ先述のような hole 濃度を増加させるために 酸素欠損をできるだけおさえることが必要だという方が 第一義的意味をもっているように思う。

ところで $\mathrm{La}_{2} \mathrm{CuO}_{4}$ に注目するとこの $\mathrm{Cu}$ 原子は $\mathrm{Cu}^{2+}$ で存在し 9 個の $\mathrm{d}$ 電子をもつ。すなわち最上の $\mathrm{d}_{x^{2}-y_{2}}$ より成るバンドには各サイト 1 個の電子（すな わち 1 個の hole) がはいっている.いわゆる half-filled バンドの状況にあるからこの化合物は金属的と予想され るが実は絶縁体的振舞をむつ。このことは Cu原子サイ トに 2 コ電子がはいったときのクーロン反発エネルギー Uが大きいことと関連している．詳細を述べるのは省 略するがこのUが大きいことと磁性を帯びることとは 密接につながっている．実際 $\mathrm{La}_{2} \mathrm{CuO}_{4-\delta}$ でも強磁性 またはスピン密度波形成による磁気的秩序が見られるこ とが, 帯磁率 ${ }^{12)}$ ，中性子散乱 ${ }^{13)}, N Q R^{14)}$ の測定結果 から知られている，スピンの方向は $\mathrm{Cu}-\mathrm{O}$ の層内にお ると思われる. しかし帯磁率の異方性や温度変化の結果 はこれでは簡単には説明できず15，今後に問題を残し ているようである。このような磁気的性質をもつ $\mathrm{La}_{2}$ $\mathrm{CuO}_{4}$ のLa原子をほんの少し $\mathrm{M}$ 原子でおきかえたよき に高温超伝導が出現するわけである.すなわち磁気的秩

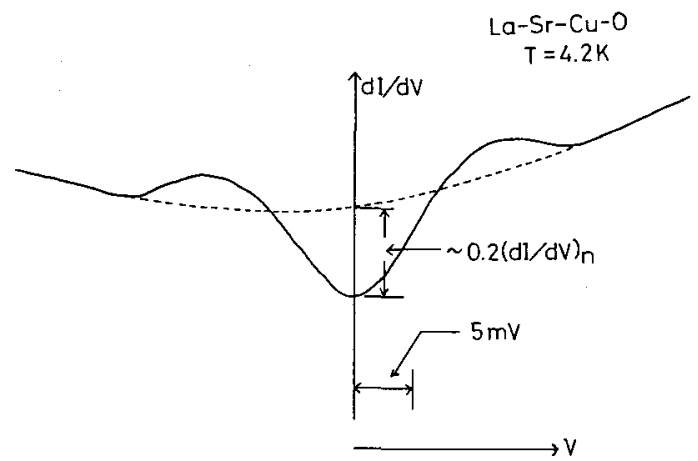

图 $3\left(\mathrm{La}_{0.925} \mathrm{Sr}_{0.075}\right)_{2} \mathrm{CuO}_{4-\delta}$ 焼結体之 $\mathrm{Al}$ の点接触型 ジャンタションで観測された微分コンダクタンス, $\mathrm{d} I / \mathrm{d} V$. 破線 は試料が常伝導の場合に推測される曲線, $(\mathrm{d} I / \mathrm{d} V)_{n}$. 実線已破 線の交点間の横軸距離が $2 \Delta / \mathrm{e}$ に対応する. $T_{\mathrm{c}}=34 \mathrm{~K}$

序と超伝導とは隣り合わせのように見え，それが Anderson $の$ Resonating Valence Bond (RVB) state をべースにした超伝導の理論 ${ }^{16)}$ に結びついた。実は $\mathrm{YBa}_{2} \mathrm{Cu}_{3} \mathrm{O}_{7-\delta}$ においてもUが大きいこ上は光電子放 出の実験 ${ }^{17)}$ 等から知られており, 超伝導と磁気とが隣 り合わせであると考える人も多い，そのため高温超伝導 を磁気的ゆらぎに関連したメカニズムで説明しようとす る試みが実に多くなされている。しばしばひき合いに出 すモリブデンブロンズやタングステンブロンズはそれぞ れ $4 \mathrm{~d}$ および $5 \mathrm{~d}$ 電子を伝導電子として持つ物質系であ り $3 \mathrm{~d}$ 電子のCu原子ほよ゙大きな $U$ をむっていない.

前述の電子励起介在の機構といい磁気的ゆらぎによる ものといい高い転移温度 $T_{\mathrm{c}}$ を探索する者にとっては大 いに勇気づけられるものであることは間遧いない。 $\mathrm{YBa}_{2} \mathrm{Cu}_{3} \mathrm{O}_{7-\delta}$ の $T_{\mathrm{c}}$ が構成元素の質量数に依存しない という実駼結果も電子格子相互作用以外の機構の存在を 支持しているように見える．しかし今後より直接的な証 拠が見つかるまでは，そう断定はしがたい．

さて機構を議論するうえで最初に注目されるのは超伝 導エネルギーギャップに関連した電子スペクトルであ る.これは電子トンネル法で測定される，これによって 従来の BCS 理論で説明できないようなエネルギー ギャップ2 $\Delta$ をもつことがあるか，いわゆるギャップレ スと呼ばれるように，完全なギャップが存在しないこと があるか,トンネルスペクトルに反映されるはずの引力 媒体の効果がどのエネルギーのあたりに見られるか，さ らにもっと詳しくはその反映された勃果の解析から $T_{\mathrm{c}}$ が再現できるか等の問に対して答えることが原理的には 可能である．測定すべき超伝導体上金属との間に絶縁膜 をはさんで電纴 $V$ をかけその薄膜を通して流れるトン ネル電流】を測定するが,このときフェルミエネルギー $\varepsilon_{\mathrm{F}}$ 近傍の電子状態密度, $N(\mathrm{eV})\left(\varepsilon_{\mathrm{F}}=0\right.$ よした $)$ は, いわゆる微分コンダタタンス $\mathrm{d} I / \mathrm{d} V$ に比例している. 
図 3 は筆者らが青山学院秋光氏らと協力してかなり早い 時期に観測した $\left(\mathrm{La}_{1-x} \mathrm{Sr}_{x}\right)_{2} \mathrm{CuO}_{4-\delta}(x=0.075)$ に関す る $\mathrm{d} I / \mathrm{d} V$ 曲線である ${ }^{18)}$ 。まだまだ完全な実験結果とは

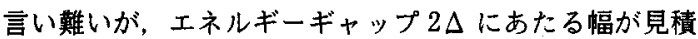
もれる.これによると $2 \Delta / k T_{\mathrm{c}} \sim 4.7$ 程度で, BCS 理 論からの值 3.52 からずれてはいるが，その延長上の強 結合理論で説明でき, $2 \Delta / k T_{\mathrm{c}}$ が 10 以上にもなるとい うスタンフォードグループの結果 ${ }^{19)}$ と比較してかなり ノーマルな值といえる. またエネルギーギャップが $\Delta$, $3 \Delta, 5 \Delta$ のよういくつかあるように見えるといういく つかの報告 19.20) に対応する構造も見られない，それら の異常な振舞の観測は実はトンネルジャンクションの抵 抗が非常に大きい場合にみられるもので本質的ではない というむきもあるので注意しなければいけない，今まで の実験結果は結局 BCS 理論の延長上の理論で説明でき ると考えているが結晶面が揃った試料を用いた最近の赤

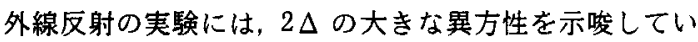
るものもあり，単結晶を用いたトンネル測定も興味のわ くところである.

\section{3 おわりに}

思いつくままに曹き進んできたが，編集者がお望みの 内容とは似ても似つかぬものになっていないかと心配す る次第である．この稿がでるころには新たなる進展がお こっていることを願って筆を擱く。

今回の高温超伝導体研究を一緒に進的てきた東北大金研。細 谷正一氏および私の研究窒の諸君に感謝申し上げます。また青 山学院秋光 純氏のグループとはトンネル効果の測定を通して 長年ご協力いただき大変うれしく思っております。また他の研 究協力者の方々，さらには分子科学研究所の所長をはじめ固体 グループの皆様のさまざまな形でのこ協力に感謝束し上げます。

\section{文献}

1) J. G. Bednorz and K. A. Müller, 2. Phys., B 64, 189 (1987)

2) 佐藤正俊，結晶学会誌，29, 190 (1987).

3) M. Sato, H. Fujișhita and S. Hoshino, "Research Report on New Superconducting Materials", Special Project Research NO. 106, Ministry of Education, Science and Culture, p. 70 (1985).
4) M.K. Wu, J.R. Ashburn, C.J. Torng, P.H. Hor, R.L. Meng, L. Gao, Z.J. Huang, Y.Q. Wang and C.W. Chu, Phys., Rev. Lett., 58, 908 (1987);S. Hosoya, S. Shamoto, M. Onoda and M. Sato, Jpn. J. Appl. Phys., 26, L 325 (1987).

5) M. W. Shafer, T. Penney and B.L. Olsen, submitted to Phys., Rev. B.

6) S. Shamoto, M. Onoda, M. Sato and S. Hosoya, Solid State Commun., 62, 479 (1987).

7) Y. Hidaka, Y. Enomoto, M. Suzuki, M. Oda and T. Murakami, Jpn. J. Appl. Phys., 26, L 377 (1987); Y. Iye, T. Tamegai, H. Takeya and H. Takei, Jpn. J. Appl. Phys., 26, L 1057 (1987).

8) N.P. Ong, Z.Z. Wang, J. Clayhold, J.M. Tarascon, L.H. Greene and W.R. McKinnon, preprint.

9) C.M. Varma, S. Schmitt-Rink and E. Abrahams, Solid State Commun., 62, 681 (1987).

10) V.Z. Kresin, Phys. Rev. B, in press.

11) S. Hosoya, S. Shamoto, M. Onoda and M. Sato, Jpn. J. Appl. Phys., 26, L 325 (1987).

12) R. L. Greene, H. Maletta, T.S. Plaskett, J.G. Bednorz and K.A. Müller, Solid State Commun., to be published

13) D. Vaknin, S.K. Sinha, D.E. Moncton, D.C.Johnston, J. Newsam, C.R. Safinyz and H.E. King Jr, Preprint.

14) Y. Kitaoka, S. Hiramatsu, K. Ishida, T. Kohara and K. Asayama, print.

15) K. Fukuda, M. Sato, S. Shamoto, M. Onoda and S. Hosoya, Solid State Commun, to be published.

16) P. W. Anderson, Science, 235, 1196 (1987).

17）たとえば T. Takahashi, F. Maeda, H. Arai, K. Katayama-Yoshida, S. Hosoya, A. Fujimori, T. Shidara, T. Koide, T. Miyahara, M. Onoda, S. Shamoto and M. Sato, Phys. Rev. B, to be published.

18) T. Ekino, J. Akimitsu, M. Sato and S. Hosoya, Solid State Commun., 62, 535 (1987).

19) M. Naito, D.P. E. Smith, M.D. Kirk, B. Oh, M. R. Hahn, K. Char, D.B. Mitzi, J.Z. Sun, D.J. Webb, M.R. Beaseley, O. Fisher, T.H. Geballe, R.H. Hammond, A. Kapitulnik and C.F. Quate, Phys. Reu. B, 35, 7228 (1987).

20) I. Iguchi, H. Watanabe, Y. Kasai, T. Mochiku, A. Sugishita, E. Yamaka, Jpn. J. Appl. Phys., 26, I. 645 (1987). 